\title{
METODE PENGAWASAN PENCEMARAN LINGKUNGAN DI KOTA PALOPO
}

\author{
Budiawan Sulaeman $^{1)}$, A. Kartini Sari ${ }^{2)}$ \\ ${ }^{1}$ Dosen Program Studi Teknik Informatika, Universitas Andi Djemma, Palopo, \\ ${ }^{2}$ Dosen Program Studi Teknik Sipil, Universitas Andi Djemma, Palopo \\ 1) budiawan.unanda@yahoo.com \\ 2) tin_sary@yahoo.com
}

\begin{abstract}
Abstrak
Tujuan penelitian ini adalah (1)untuk menjelaskan metode pengawasan pencemaran lingkungan (2)untuk menjelaskan pengelolaan drainase, dan (3)untuk menganalisis apakah ada hambatan dalam pengawasan pencemaran lingkungan dan pengelolaan drainase di Kelurahan Pontap Kecamatan Wara Timur serta bagaimana mengatasinya.Tabel frekuensi dari hasil penelitian, menunjukkan rata-rata 277,23 dan dengan menggunakan skala likert masuk pada gradasi puas. Penelitian ini dapat disimpulkan bahwa Metode Pengawasan Pencemaran Lingkungan Kota palopo dan pengelolaan drainase yang difokuskan di Kelurahan Pontap berjalan dengan baik atau dengan kata lain masyarakat puas terhadap metode pengawasan yang diberikan oleh pihak Pemerintah Kelurahan Pontap Kecamatan Wara Timur Kota Palopo. Adapun hambatan yang timbul dalam pelaksanaan pengwasan lingkungan di Kelurahan Pontap yaitu penggunaan drainase yang kurang maksimal karena masih ada warga dan para pengusaha kurang menyadari akan pentingnya drainase dalam kebersihan suatu lingkungan serta keterkaitannya dengan peningkatan perekonomian masyarakat. Dinas Kebersihan dan Pertamanan Kota Palopo sebaiknya menambah unit kontainer sampah (koordinat: S 2 $59^{\prime} 08^{\prime \prime}$ E $\left.120^{\circ} 11^{\prime} 55^{\prime \prime}\right)$ yang akan ditempatkan di Kelurahan Pontap Kecamatan Wara Timur.
\end{abstract}

Kata Kunci: pencemaran lingkungan, Kelurahan Pontap

\section{PENDAHULUAN}

Masih banyak sekali penduduk yang tinggal di tempat-tempat kumuh di Indonesia karena kekurangan sulitnya mendapatkan biaya untuk menghidupi dirinya dan keluarganya. Akhirnya mereka menyewa rumah dengan harga yang murah. Biasanya karena harga murah tersebut, lingkungan yang ada di sekitarnya itu jauh dari kata bersih. Mulai dari pembuangan kotorannya hingga penyediaan air bersih. Masih banyak penduduk Indonesia yang tidak memiliki tempat pembuangan tinja dan melakukan praktik buang air besar (BAB) sembarangan. Padahal kebersihan lingkungan, terkait pembuangan $\mathrm{BAB}$ di sembarang tempat akan berhubungan dengan tercemarnya sekitar lingkungan rumah penduduk tersebut.

Pada tahun 2015 pemerintah kota palopo telah melaksanakan pembangunan sistem drainase di Kota Palopo, yang merujuk pada undang-undang nomor 32 tahun 2009, tentang Perlindungan dan Pengelolaan Lingkungan Hidup (PPLH). Lingkungan hidup adalah kesatuan ruang dengan semua benda, daya, keadaan, dan makhluk hidup, termasuk manusia dan perilakunya, yang mempengaruhi alam itu sendiri, kelangsungan perikehidupan, dan kesejahteraan manusia serta makhluk hidup lain. PPLH adalah upaya sistematis dan terpadu yang dilakukan untuk melestarikan fungsi lingkungan hidup dan mencegah terjadinya pencemaran dan/atau kerusakan lingkungan hidup yang meliputi perencanaan, pemanfaatan, pengendalian, pemeliharaan, pengawasan, dan penegakan hukum.

Program ini bertujuan untuk perlindungan dan pengelolaan lingkungan hidup dilaksanakan berdasarkan asas tanggung jawab pemerintah, kelestarian dan keberlanjutan, keserasian dan keseimbangan, keterpaduan, manfaat, kehati-hatian, keadilan, ekoregion, keanekaragaman hayati, pencemar membayar; partisipatif, 
kearifan lokal, tata kelola pemerintahan yang baik serta otonomi daerah. Pada tahun yang sama pemerintah membuat program seribu jamban guna menepati janji walikota terpilih dalam mengatasi pencemaran lingkungan.

Berdasarkan hasil survey, pencemaran lingkungan dan pertumbuhan penduduk signifikan membuat Kelurahan Pontap Kecamatan Wara Timur Kota Palopo menjadi fokus dalam penelitian. Hal ini diperkuat dengan adanya Pasar Andi Tadda yang menjadi penyumbang sampah terbesar di kelurahan tersebut. Daerah ini dulunya merupakan lahan resapan air, kini beralih fungsi menjadi kawasan pemukiman, industri dan perdagangan.

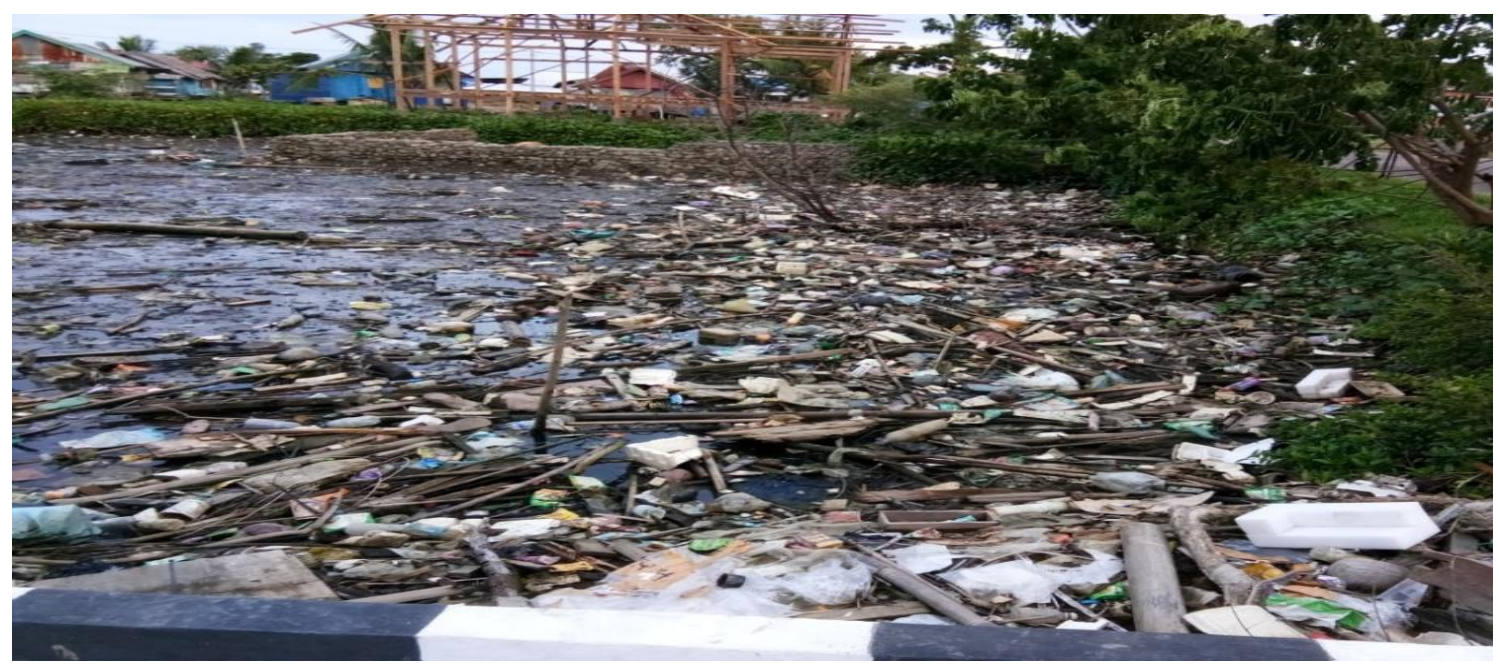

Gambar 1. Kawasan Pasar Andi Tadda Kel. Pontap Kec. Wara Timur Kota Palopo

(Koordinat : S 2० 59' 25" E $120^{\circ} 11^{\prime}$ '52")

Untuk menciptakan lingkungan yang baik, sehat, dan bersih tentunya diperlukan suatu perangkat peraturan yang dapat mendukung terciptanya lingkungan yang baik, sehat, dan bersih serta diperlukannya pengawasan.

\section{Konsep Manajemen Perkotaan}

Secara umum manajemen perkotaan (urban management) adalah suatu upaya proses pelaksanaan rencana kota untuk mencapai sasaran pembangunan kota secara efisien dan efektif. Sedangkan menurut Achmad Nurmandi mangemukakan bahwa manajemen perkotaan merupakan pendekatan yang kontemporer untuk menganalisis permasalahan perkotaan. Lea dan Courtney (Achmad Nurmandi, 2006 : 125) membedakan dua pendekatan manajemen perkotaan, yaitu pendekatan problemoriented teknokratis dan pedekatan ekonomi politik struktural. Pendekatan pertama lebih memfokuskan pada peningkatan kinerja lembaga-lembaga yang ada dan memecahkan masalah-masalah perkotaan. Sedangkan pendekatan kedua lebih memfokuskan pada pada akar permasalahan perkotaan dalam konteks ekonomi politik nasioal dan internasional. Dalam proses pengelolaan suatu wilayah perkotaan melibatkan banyak sektor, bidang dan stakeholder. Secara umum pengelolaan perkotaan dibagi menjadi 2 (dua) yaitu, bidang fisik dan non-fisik. Bidang fisik adalah segala sesuatu sumberdaya pengelolaan infrastruktur kota termasuk upaya konservasi sumberdaya alam yang berpengaruh pada pembangunan kota, sedangkan bidang non-fisik adalah semua yang berkaitan dengan pengembangan kualitas sumberdaya manusia dan kelembagaan kemasyarakatan, kelembagaan, perekonomian kota dan sistem pengeawasan serta pengendalian pembangunan kota. 


\section{Pelayanan Publik Perkotaan}

Merupakan bagian utama dari fungsi pemerintah kota. Upaya untuk memberikan pelayanan yang baik dan menjangkau seluruh kelompok masyarakat yang bersifat heterogen adalah hal yang paling rumit. Hasil survei yang dilakukan UNDP (dalam Achmad Nurmandi, 2006 : 335) menyimpulkan bahwa masalah pengangguran adalah masalah yang paling serius, diikuti dengan perumahan, manajemen persampahan, kekerasan dan kriminalitas, kemiskinan, sanitasi yang tidak baik, polusi udara, transportasi publik yang jelek, pelayanan air bersih yang masih kurang, kekurangan dalam pendidikan dan kesehatan, rendahnya partisipasi sosial, dan diskriminasi menurut garis etnis, gender, dan status ekonomi. Selain masalah pengangguran, menururt persepsi para walikota di dunia masalah laian yang ada adalah tidak memadainya pelayanan publik, mulai dari pelaayanan dasar lingkungan sampai dengan buruknya aksesibilitas pelayanan itu sendiri. Penerapan teknologi baru dalam pelayanan publik merupakan suatu hal yang tidak dapat dihindari dalam mempercepat pemberian pelayanan seiring dengan semakin meningkatnya jumlah konsumen yang membutuhkannya. Disadari bahwa manusia tidak dapat mengandalkan kemampuan manual aparat pemerintah dalam memenuhi kebutuhan setiap konsumen yang ada. Organisasi pelayanan publik harus scara cepat membuat inovasi-inovasi di bidang teknologi untk meningkatkan kinerja organisasinya.

\section{Pengawasan}

Pengertian Pengawasan adalah proses pengamatan dari pada pelaksanaan seluruh kegiatan organisasi untuk menjamin agar supaya semua pekerjaan yang sedang dilakukan berjalan sesuai dengan rencana yang telah ditentukan sebelumnya. Prosedur untuk menetapkan sistem pengawasan terdiri atas lima langkah dasar yang dapat diterapkan pada semua tipe kegiatan pengawasan yaitu meneruskan hasil yang diinginkan, menetapkan petunjuk (Predictors) hasil, menetapkan standar petunjuk dan hasil, menetapkan jaringan informasi dan umpan balik serta menilai informasi dan mengambil tindakan koreksi. (2) Arti dan Fungsi Pengawasan Pemerintah dalam penyelenggarakan pemerintah dari sudut Ilmu Administrasi Negara adalah mencegah timbulnya bentuk penyimpangan tugas pemerintah dari apa yang telah digariskan (preventif) dan menindak atau memperbaiki penyimpangan yang terjadi (represif). Pengawasan dari pandangan ilmu administrasi negara adalah terletak pada Perda yang ditetapkan oleh Walikota Palopo sebagai landasan kerja atau pedoman dalam melakukan tugasnya menyelenggarakan pemerintahan. George R. Tery (2006:395) mengartikan pengawasan sebagai mendeterminasi apa yang telah dilaksanakan, maksudnya mengevaluasi prestasi kerja dan apabila perlu, menerapkan tidankantindakan korektif sehingga hasil pekerjaan sesuai dengan rencana yang telah ditetapkan.

\section{Sanitasi Lingkungan}

Merupakan salah satu komponen dari kesehatan lingkungan, yaitu perilaku yang disengaja untuk membudayakan hidup bersih untuk mencegah manusia bersentuh langsung dengan kotoran dan bahan buangan berbahaya lainnya, dengan harapan dapat menjaga dan meningkatkan kesehatan manusia. Sanitasi lingkungan adalah status kesehatan suatu lingkungan yang mencakup perumahan, pembangunan, pembuangan kotoran, penyediaan air bersih, dan sebagainya. Kesehatan lingkungan di Indonesia masih memprihatinkan. Belum optimalnya sanitasi di Indonesia ini ditandai dengan masih tingginya angka kejadian penyakit infeksi dan penyakit menular di masyarakat. Sanitasi sangat menentukan keberhasilan dari paradigma pembangunan kesehatan 
lingkungan lima tahun ke depan yang lebih menekankan pada aspek pencegahan dari aspek pengobatan. Dengan adanya upaya pencegahan yang baik, angka kejadian penyakit yang terkait dengan kondisi lingkungan dapat di cegah. Selain itu anggaran yang diperlukan untuk preventif juga relative lebih terjangkau daripada melakukan upaya pengobatan penyakit, banjir, pandangkalan saluran/sungai, tersumbatnya saluran sungai, dialirkan pada saluran sungai. Dengan memperhatikan (1). Manfaat Sanitasi, (2) Keadaan Sanitasi dan Kesehatan Lingkungan, (3) Upaya Menangani Masalah Sanitasi Lingkungan, (4) Pemeliharaan dan Dukungan Teknis.

\section{Drainase}

Merupakan salah satu fasilitas dasar yang dirancang sebagai komponen penting dalam perencanaan kota khususnya perencanaan infrastruktur. Secara umum, drainase didefinisikan sebagai serangkaian buangan air yang berfungsi untuk mengurangi dan atau membuang kelebihan air dari suatu kawasan/ lahan sehingga dapat difungsikan secara optimal. Menurut Suripin (2004: 7), drainase mempunyai arti mengalirkan menguras, membuang, atau mengalihkan air. Drainase juga diartikan sebagi suatu cara pembuangan kelebihan air yang tidak diinginkan pada suatu daerah serta cara penanggulangan akibat yang ditimbulkan oleh kelebihan air tersebut. Saluran drainase berfungsi untuk mengeringkan daerah becek dan genangan air yang menyebabkan terjadinya banjir. Selain itu saluran drainase juga berfungsi mencegah terjadinya erosi tanah, kerusakan jalan, dan lain-laian. Sistem saluran drainase umumnya dibag atas dua bagian, yaitu: (1) Sistem darinase makro (2) Sistem drainase mikro

\section{METODOLOGI PENELITIAN \\ Lokasi dan Waktu}

Penelitian ini dilaksanakan di Kelurahan Pontap Kecamatan Wara Timur dan Dinas Tata Ruang dan Cipta Karya Kota Palopo serta berfokus pada dampak (impact), lembaga pemerintah yang berkelanjutan (sustainability), kerangka institusional dan proses pembuatan, efisiensi dan informasi. Dalam penelitian ini membutuhkan waktu selama \pm 5 bulan. Mulai Bulan April sampai dengan Bulan Agustus 2018

\section{Pendekatan Penelitian}

Menggunakan pendekatan kualitatif dimana dalam penelitian ini yang dilakukan bersifat deskriptif. Artinya penulis menggunakan wawancara, catatan laporan, dan observasi langsung ke lapangan untuk mnggambarkan fenomena yang berhubungan dengan inovasi dalam pengelolaan drainase di Kota Palopo.

\section{Tipe Penelitian}

Tipe penelitian yang digunakan adalah tipe penelitian deskriptif. Penelitian deskriptif (penggambaran) ini merupakan suatu penelitian yang akan memprediksikan mengenai pelaksanaan manajemen perkotaan terhadap pengawasan pencemaran lingkungan di Kelurahan Pontap Kecamatan Wara Timur Kota Palopo. Hal ini dilakukan untuk mendeskripsikan, mencatat, menganalisa, dan menginterpretasikan kondisi yang terjadi saat ini.

\section{Rancangan Penelitian}

Menggunakan penelitian kualitatif adalah kata-kata dan tindakan, selebihnya adalah data tambahan seperti dokumen pendukung. Data hasil penelitian didapatkan melalui dua sumber yaitu: (1) Data primer dan (2) Data sekunder. 


\section{Teknik Analisis Data}

Langkah - langkah yang dilakukan setelah pengumpulan data sebagai berkut: (1) Reduksi data berarti merangkum, memilih hal yang pokok, memfokuskan pada sesuatu yang dianggap penting, dicari tema dan polanya. Dengan demikian data yang telah direduksi akan memberikan gambaran yang lebih jelas dan mempermudah peneliti untuk melakukan pengumpulan data selanjutnya, serta mencarinya bila diperlukan. (2) Penyajian data Setelah data reduksi, maka langkah selanjutnya adalah menyajikan data. Dalam penelitian kualitatif, penyajian data bisa dilakukan dalam bentuk uraian singkat, bagan, hubungan antar kategori, flowchart, dan sebagainya. Akan tetapi yang paling sering digunakan untuk menyajikan data dalam penelitian kualitatif adalah dengan teks yang bersifat naratif. (3) Penarikan kesimpulan, Langkah selanjutnya dalam analisis data kualitatif adalah penarikan kesimpulan dan verifikasi. Kesimpulan awal yang dikemukakan masih bersifat sementara, dan akan berubah bila tidak ditemukan bukti yang kuat yang mendukung pada tahap pengumpulan data berikutnya. Tetapi apabila kesimpulan yang dikemukakan pada tahap awal, didukung oleh bukti yang valid dan konsisten saat peneliti kembali ke lapangan mengumpulkan data, maka yang dikemukakan merupakan kesimpulan yang kredibel.

\section{HASIL DAN PEMBAHASAN}

Sanitasi merupakan salah satu komponen dari kesehatan lingkungan, yaitu perilaku yang disengaja untuk membudayakan hidup bersih untuk mencegah manusia bersentuh langsung dengan kotoran dan bahan buangan berbahaya lainnya, dengan harapan dapat menjaga dan meningkatkan kesehatan manusia. Sanitasi sangat menentukan keberhasilan dari paradigma pembangunan kesehatan lingkungan lima tahun ke depan yang lebih menekankan pada aspek pencegahan dari aspek pengobatan. Selain itu anggaran yang diperlukan untuk preventif juga relative lebih terjangkau daripada melakukan upaya pengobatan penyakit, banjir, pandangkalan saluran/ sungai, tersumbatnya saluran sungai, dialirkan pada saluran sungai. Di Kelurahan Pontap tingkat kehidupan masyarakat sudah dapat dikatakan kurang baik. Hal ini dibuktikan hasil observasi lapangan, dimana masyarakat yang menjadi responden yang bekerja lain - lain (IRT, Penjual Ikan, Buru Lepas, Penjual Sayur atau pekerja serabutan) mencapai 61 orang dari 80 orang responden atau sekitara $78 \%$. Dapat pula dilihat dari kondisi daerah sekitar masih banyak masyarakat yang tinggal diaerah yang kumuh.

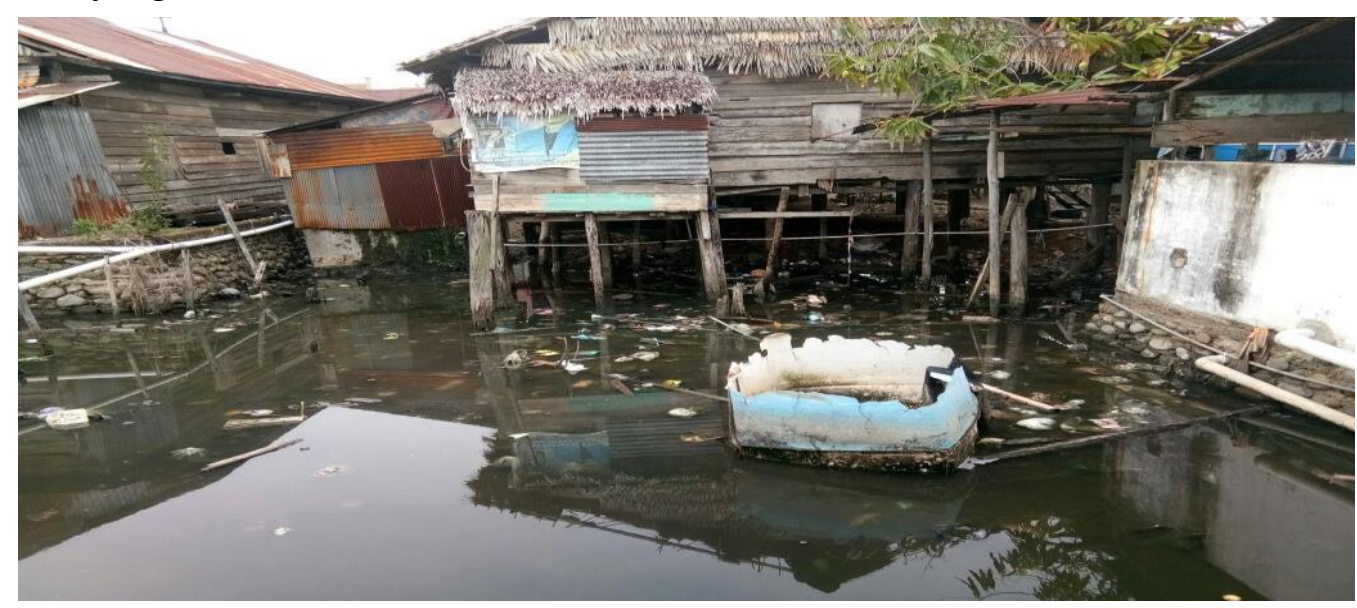

Gambar 2. Salah satu sudut di Kelurahan Pontap Kota Palopo (Koordinat : S 2 59 '15” E 120¹1'52”) 
Untuk mengetahui tingkat kesadaran masyarakat Kelurahan Pontap dalam pengaruh sanitasi terhadap lingkungan yang akan meningkatkan pertumbuhan ekonomi pada masyarakat 36 orang responden atau 45\% mengatakan berpengaruh, Hal senadapun di katakan oleh Ibu Junita anjar Lestari, SS. (Lurah Pontap). Dengan adanya sanitasi lingkungan yang berfungsi dengan baik, dapat dikatakan hal tersebut sangat mendukung pertumbuhan perekonomian masyarakat, karena masyarakat tidak lagi dibayang - bayangi oleh penyakit yang dapat menimpah akibat kondisi sanitasi yang tidak baik.

Sanitasi di kelurahan Pontap dapat meningkatkan kualitas kesehatan, pendidikan, dan produktivitas masyarakat. $51 \%$ responden menyatakan meningkat. Realisasi dilapangan masyarakat antusias dalam menjaga kebersihan lingkungan seperti yang diperlihatkan pada kampung KB RW II RT 3 Kelurahan pontap Kota Palopo. Dengan cara menghiasi lingkungan tersebut agar sedap dipandang mata. Begitupun dengan Drainase yang ada disekitarnya tertata rapi, sehingga air mengalir dari tempat yang tinggi ketempat yang rendah. Menurut Bapak Masdar, ST (Kabid Pengawasan Perumahan dan pemukiman) Dinas Tataruang dan Pemukiman Kota Palopo, Kami sudah mengusulkan untuk menganggarkan perbaikan drainase di beberapa kelurahan pesisir untuk meningkatkan kualitas pertumbuhan ekonomi, pendidikan dan produktifitas masyarakat. Salah satu kelurahan tersebut adalah kelurahan Pontap Kecamatan Wara Timur Kota Palopo. Dengan adanya program tersebut kami selaku pemerintah daerah juga menghimbau agar nantinya masyarakat dapat menjaga kebersihan dan memberi perawatan terhadap pembangunan drainase trsebut. Dan saat ini sedang berlangsung pembagunan IPAL di beberapa kelurahan yang ditargetkan selesai akhir tahun ini.

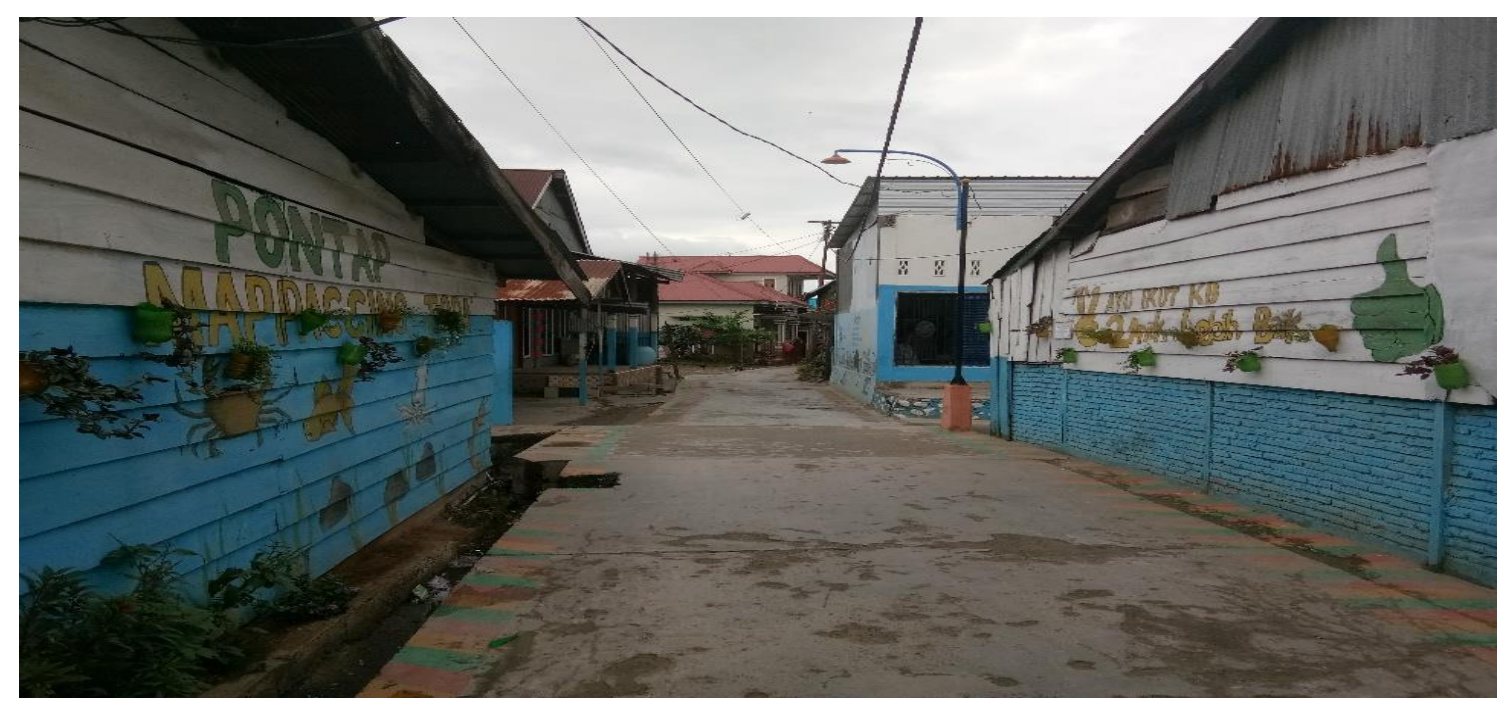

Gambar 3. Kampung KB Kelurahan Pontap Kota Palopo

(Koordinat : S 2०59'17' E 120¹1'55”)

Pemerintah Kota palopo sangat mendukung pembangunan dan mengimplementasikannya dengan cara memebangun Instalasi Pengelolaan Air Limba (IPAL) di Kelurahan Pontap Kecamatan Wara Timur Kota Palopo. Dalam pepbangunannya pemerintah kota palopo menggelontorkan dana APBD Tahun Anggaran 2017 sebesar Rp. 427.500.000, yang dilaksanakan oleh KSM Tangjung Ringgit Kelurahan Pontap Kecamatan Wara Timur Kota Palopo. 


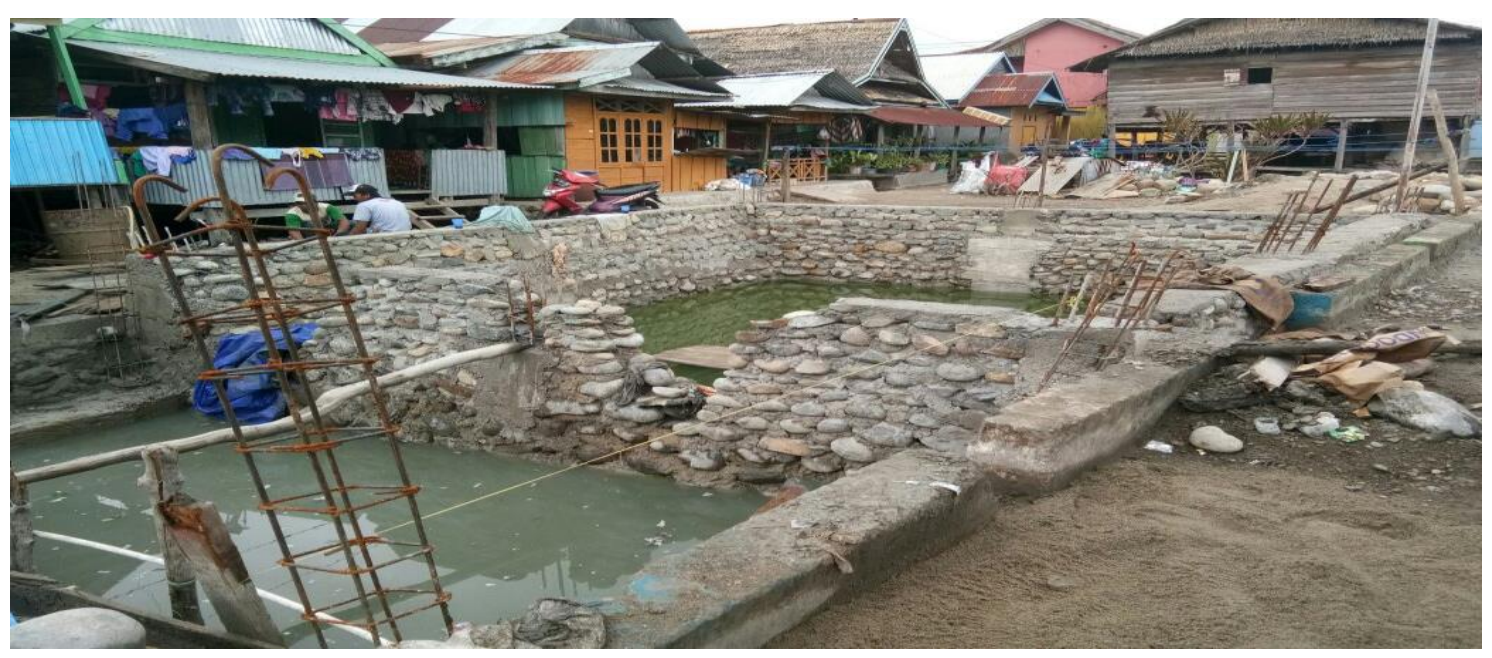

Gambar 4. Pembangunan Instalasi Pengelohan Air Limbah (IPAL)

(Koordinat : S 2०59'13" E 120¹1'56”)

Dari 80 orang responden 64 orang menyakan Pemerintah Kelurahan Pontap dalam pembangunan sanitasi di kelurahan Pontap memberdayakan masyarakat. Ini dapat dilihat dalam pembangunannya, IPAL Kelurahan Pontap, menggukanan tukang atau masyarakat yang berdomisilih di kelurahan tersebut. Hal senadapun dikatakan oleh Bapak Ir. Kadrang Ketua LPMK Pontap, Masyarakat dilibatkan dalam pembangunannya. Hal ini kami lakukan agar masyarakat dalam hal pemeliharaan IPAL tersebut rasa memilikinya juga ada, supaya dalam perawatannya masyarakat juga mengambil andil untuk menjaga kelangsungan yang bersinambungan agar IPAL tersebut dapat difungsikan secara maksimal. Begitupun dengan pembangunan drainase yang dianggarkan pada dua tahun lalu, semua pekerja yang dipekerjakan berasal dari masyarakat Kelurahan Pontap, sekaligus untuk menekan jumlah pengangguran yang berada di kelurahan tersebut.

Pencegahan penyakit lebih murah dari pada mengobati, masih ada mayarakat yang belum memahami akan slogan tersebut, walaupun pemerintah sering melakukan sosialisasi di tingkat kecamatan maupun di tingkat Kelurahan. Hal ini dapat ditunjukkan di pinggiran Kelurahan Pontap yang berbatasan lansung dengan Kelurahan Ponjalae. Dan tak dapat pula dipungkiri, perbatasan tersebut terdapat pasar rakyat Andi Tadda sehingga dalam penerapan dan implementasi sanitasi yang baik sangat jauh dari harapan yang diinginkan bersama.

Dari 80 orang responden sangat merespon dengan aturan yang diberikan oleh pemerintah dalam hal menjaga lingkungan di kelurahan pontap sehingga tidak mencemari sungai. Akan tetapi belum adanya aturan atau regulasi dari pemerintah Kota Palopo yang mengatur tentang sanitasi lingkungan. Hal senadapun dikatakan oleh ibu Lurah Pontap "regulasi belum ada dikeluarkan atau yang ditetapkan oleh Pemerintah Kota Palopo", namun kami dilapangan sering mengadakan sosialisasi terhadap kebersihan lingkungan.

Dari 80 orang responden $53 \%$ menyatakan membantu pemerintah dalam hal menggalakkan pemeliharaan sanitasi dilingkungan sehingga dapat membantu untuk menekan penyakit yang berhubungan dengan air. Karena September 2016 pernah terjadi salah satu warga yang tinggal dikelurahan Pontap terkenah penyakit demam berdarah. Ini menjadi kejadian yang luar bisa terjadi bagi Masyarakat Kota Palopo, yang menyandang Piala Adipura sebagai parameter untuk kota yang telah bebas dari Jentik Nyamuk demam berdarah. Tapi kejadian tersebut sudah di tanggulangi oleh 
dinas Kesehatan dengan mengadakan penyoprotan fogging secara berkala di kelurahan tersebut (1 kali dalam setahun).

Responden 58 orang atau $73 \%$ menyatakan dirumahnya terdapat toilet untuk BAB. Namun masih ada warga atau sekitar $27 \%$ yang belum mempunyai toilet. Dari hasil dilapangan dan wawancara beberapa masyarakat, menyatakan untuk BAB mereka mengandalkan $w c$ umum yang terdapat disekitar pemukiman penduduk atau langsung ke sungai apabila malam hari. Menurut ibu Lurah, secara perlahan - lahan pemerintah kota palopo, memberikan bantuan kepada masyarakat yang kurang mampu dalam hal pembanguanan wc/toilet didalam rumah mereka ditahun anggaran ini pemerintah menganggarkan $15 \mathrm{KK}$ untuk mendapatkan $w c /$ toilet secara gratis kepada masyarakat yang kurang mampu, karena tidak dapat dipungkiri masyarakat Kelurahan Pontap masih ada yang hidup dibawah garis kemiskinan sehingga untuk mengadakan wc/toilet didalam rumah sendiri sangat berat untuk mengadakannya dan mereka berharap adanya bantuan yang diberikan oleh pemerintah untuk meringankan biayanya pembangunannya.

Penggunanan toilet/wc di rumah sangat membantu menekan volume penggunaan air. Hal senadapun di katakan oleh Bapak Ir. Kadrang Ketua LPMK Pontap. Karena dalam penggunaan air masayakat, dapat mengirit setiap liter airnya.

Sebanyak 100\% masyarakat di kelurahan pontap menggunakan air bersumber dari PDAM untuk penggunaan MCK. Karena disekitar kelurahan Pontap apabila menggunakan air sumur, kualitas air tidak bagus karena disekitar pemukiman penduduk terdapat banyak lumbung - lumbung genangan air yang kurang kondusif. Sehingga mencemari air dan lingkungan sekitarnya. Namun disayangkan, asupan air yang sampai di kelurahan Pontap masih tergolong minim disiang hari. Tak dapat dipungkiri karena kelurahan pontap berada dekat dengan pantai sehingga asupan air dari PDAM Kota Palopo sangat jauh, tinggal yang tersisa saja yang sampai di kelurahan tersebut. Dikarenakan telah digunakan oleh masyarakat Kota Palopo yang tinggal dengan radius yang dekat dengan sumber PDAM Kota Palopo, sehingga air yang sampai di Kelurahan Pontap jauh dari harapan, dan ketika pukul $24.00-03.00$ malam, air baru lancar kembali karena penggunaan air oleh masyarakat yang radiusnya dekat dengan PDAM tidak menggunakan air. Hal ini juga dapat menjadi perhatian khusus buat PDAM Kota Palopo untuk membangun pipa tersendiri bagi masyarakat pinggiran kota atau membuat bak penampungan sementara di setiap kelurahan yang terdapat di pinggiran kota. Karena penggunaan air bersih sangat bermanfaat bagi kesehatan masyarakat dan lingkungannya. Sehingga sangat diperlukan untuk mengadakan kajian khusus terhadap kasus ini.

Dari 80 orang responden sangat merespon dengan aturan yang diberikan oleh pemerintah, karena disetiap depan lorong pemerintah menyiapkan tempat pembuangan sampah sementara (TPS) yang diangkut oleh dinas keberishan setiap hari (pagi dan sore hari). Hal senadapun disampaikan oleh ibu Lurah Pontap, TPS selalu di kontrol oleh pegawai kelurahan disetiap harinya dan apabila dinas kebersihan tidak melakukan tugasnya sebagaimana mestinya. Petugas kelurahan Pontap dapat langsung komplain di Dinas Kebersihan dan Pertamanan Kota Palopo untuk memintah pertanggung jawaban. Ini mereka lakukan agar supaya dapat menyadarkan masyarakat akan pentingnya kesehatan bagi pertumbuhan perekonomian. 


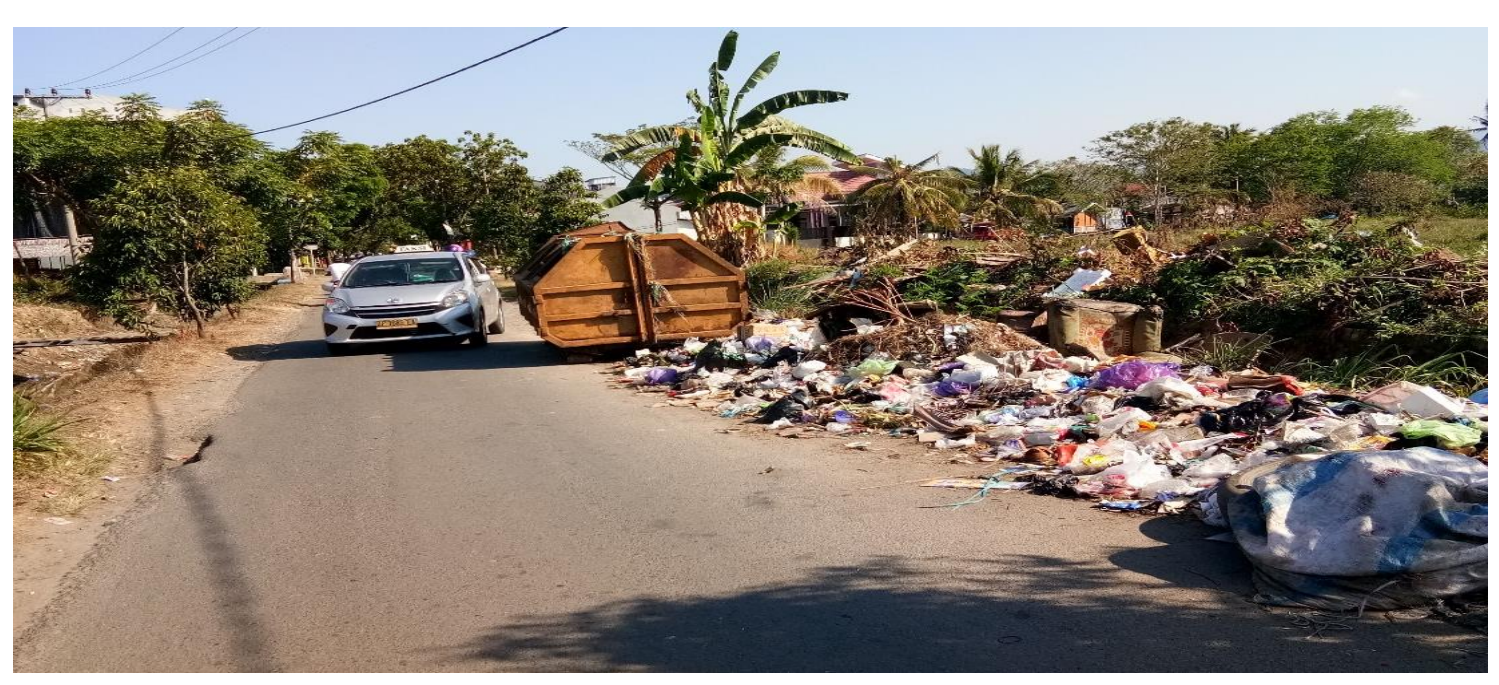

Gambar 5 : Kondisi salah satu TPS di Kelurahan Pontap

(Koordinat : S 2०59'08' E 120¹1'55”)

Hal yang dijumpai di lapangan, terkadang masyarakat membuang sampah di luar kontainaer yang telah disiapkan. Ini terjadi bukan karena sebab, terkadang kontainer belum datang dari Tempat Pembuangan Akhir (TPA) di Kecamatan Mancani Kota Palopo. Dan masyarakat datang langsung membuang sampah. Sehingga pada saat kontainer datang sampah sudah berserahkan (lihat gambar). Begitupun yang dikatakan oleh Ibu Nurhaeni (Ketua RT. 1 Kelurahan Pontap). Sebaiknya sebelum mengangkat kontainer sampah dari TPS, 1 Unit kontainer telah disiapkan sebelumnya untuk mencegah hal ini terjadi.

Lembaga pemerintah (kelurahan, kecamatan dan lembaga terkait) pernah/sering mengadakan sosialisasi terhadap pengelolaan limbah rumah tangga dan industri di Kelurahan Pontap, masih ada masyarakat yang kurang respon terhadap sosialisasi pengolahan limbah rumah tangga. Hal ini karena masyarakat yang dijadikan responden mayoritas adalah IRT, penjual ikan, buru lepas, penjual sayur atau pekerja serabutan yang mencapai $78 \%$. Yang pada saat sosialisasi berlangsung mereka tidak hadir atau mungkin saja, ketua RT dan RW tidak menyampaikan akan pentingnnya pengelolaan limbah rumah tangga dan industri di Kelurahan Pontap. Menurut ibu lurah, Kami sering mengundang pihak pemerintah dalam hal ini kepala Bapeda atau yang mewakili dan dinas tata ruang dan pemukiman, terkait mensosialisasikan pengelolaan limbah rumah tangga dan industri di Kelurahan Pontap. Karena menjadi salah satu agenda tahunan yang telah dibuat oleh pihak kelurahan dalam hal mensejahterakan masyarakat di Kelurahan Pontap. Kegiatan inipun dihadiri oleh beberapa LSM, Ketua LPMK Pontap, Pengusaha, RT dan RW sekelurahan Pontap.

Lembaga Swadaya Masyarakat (LSM) di Kelurahan Pontap. pernah/sering mengadakan sosialisasi terhadap pengelolaan limbah rumah tangga dan industri di Kelurahan Pontap. Menurut data yang ditemukan dilapangan bahwa LSM jarang memberikan sosialisasi terhadap pengolahan limbah rumah tangga dan industri. Sebagian LSM bekerja hanya pada saat ada proyek yang digelontorkan oleh pemerintah sebagai pengawal pembangunan di Kelurahan Pontap. Usaha Kecil/Menengah (UKM) yang berada disekitar Kelurahan Pontap. sering membantu masyarakat dalam pengelolaan limbah yang diakibatkan oleh industri tersebut. Namun yang yang ditemukan dilapangan masih ada beberapa pengusaha ikan kering membuang sisa pencucian ikannya (belum diolah atau diproses sebelumnya agar tidak 
mencemari lingkungan) di selokan yang menjadi drainase utama kebutuhan masyarakat.

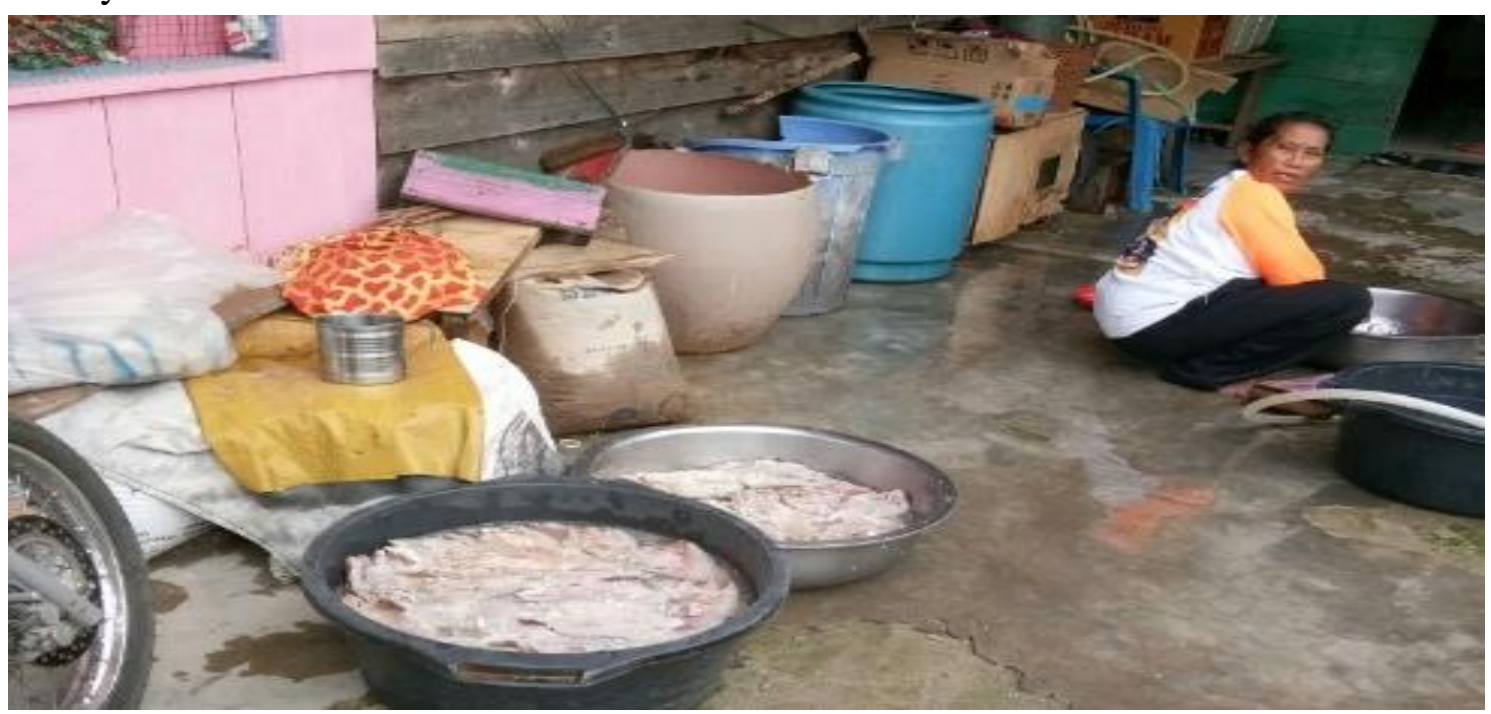

Gambar 6. Salah satu Industri Pengolahan Ikan Kering

(Koordinat: S 2०59'14” E $120^{\circ} 11$ '57”)

Hasil yang ditemukan dilapangan penelitian Metode Pengawasan Pencemaran Lingkungan Kota Palopo yang difokuskan di Kelurahan Pontap, menurut Nugroho Tri Utomo teridiri dari;

a. Pengaruh sanitasi terhadap lingkungan sangat meningkatkan pertumbuhan ekonomi di kelurahan pontap. (K1)

b. Sanitasi di kelurahan Pontap sangat meningkatkan kualitas kesehatan, pendidikan, dan produktivitas masyarakat. (K2)

c. Pemerintah Kota Palopo dalam mengimplementasikan sanitasi di kelurahan pontap dapat membantu menurunkan angka kemiskinan. (K3)

d. Pembangunan sanitasi di kelurahan Pontap memberdayakan masyarakat dalam pembangunannya. (K4)

e. Pembangunan sanitasi yang diatur oleh pemerintah dapat mencegah penyakit sehingga menyehatkan masyarakat di kelurahan pontap (mencegah penyakit selalu lebih murah daripada mengobati). (K5)

f. Adanya sanitasi yang diatur oleh pemerintah kota palopo dapat menjaga lingkungan di kelurahan pontap sehingga tidak mencemari sungai. (K6)

g. Adanya sanitasi dilingkungan saudara, dapat membantu untuk menekan penyakit yang berhubungan dengan air. (K7)

h. Penggunanan toilet dirumah saudara dapat membantu menekan volume penggunaan air (K8)

i. Menggunakan Air bersih untuk keperluan sehari-hari yang kualitasnya memenuhi syarat kesehatan dan dapat diminum apabila telah dimasak. (K9)

j. Pembuangan sampah sementara (TPS) di kelurahan pontap berfungsi sebagaiman mestinya/ pemerintah Kota Palopo memberi pelayanan yang baik terhadap TPS di kelurahan Pontap. (K10)

k. Lembaga Pemerintah (Kelurahan, Kecamatan dan lembaga terkait) pernah/sering mengadakan sosialisasi terhadap pengelolaan limbah rumah tangga dan industri di kelurahan Pontap. (K11) 
1. Lembaga Swadaya Masyarakat (LSM) di Kelurahan Pontap. pernah/sering mengadakan sosialisasi terhadap pengelolaan limbah rumah tangga dan industri di kelurahan Pontap. (K12)

m. Usaha Kecil/Menengah (UKM) yang berada disekitar Kelurahan Pontap. Pernah/sering membantu masyarakat dalam pengelolaan limbah yang diakibatkan oleh industri tersebut. (K13)

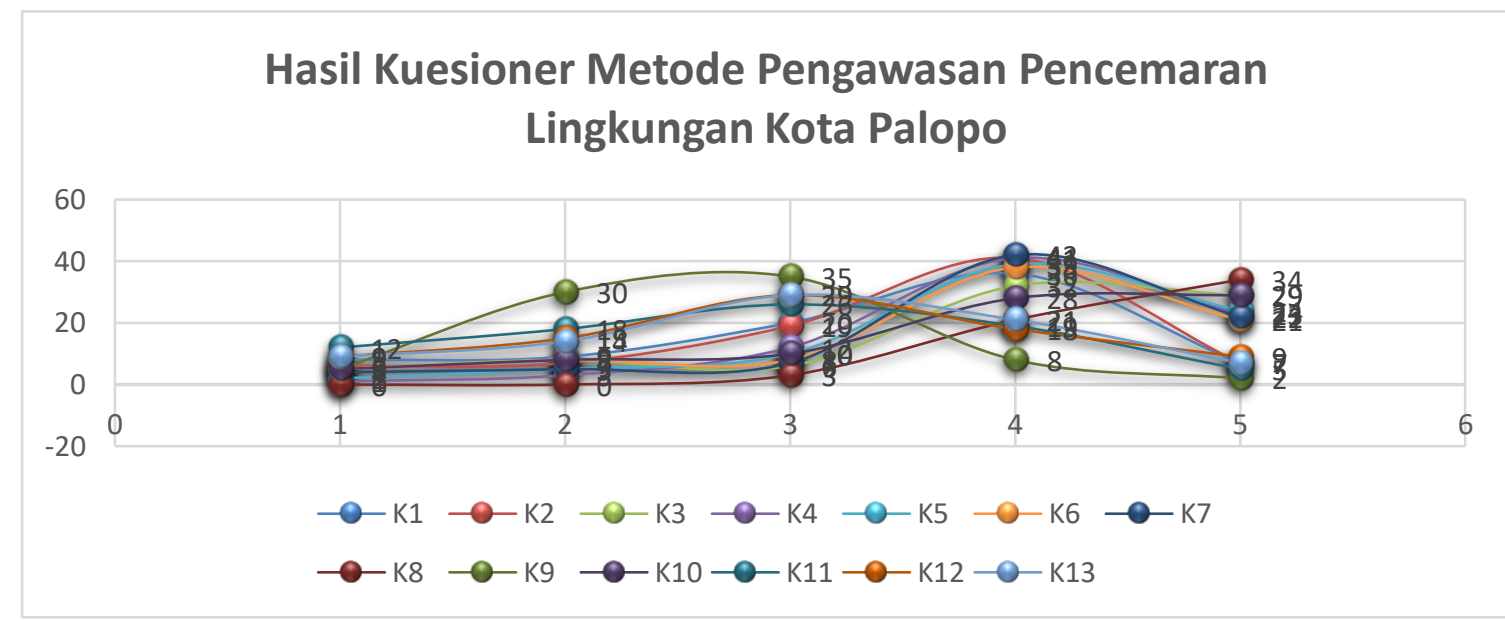

Gambar 7. Grafik Hasil Kuesioner

Grafik hasil kuesioner menunjukkan bahwa dalam pengawasan pencemaran lingkungan di Kelurahan Pontap Kecamatan Wara Timur Kota Palopo sangat berpariatif. Hal ini terjadi karena pola pikir warga yang berbeda antara satu dengan yang lain. Begitupun kondisi air bersih yang ada di Kelurahan Pontap, perlu diadakan penanganan khusus oleh PDAM Kota Palopo sehingga masyarakat dapat menggunakan air secara maksimal.

Rekapitulasi kuesioner responden, sebagai berikut;

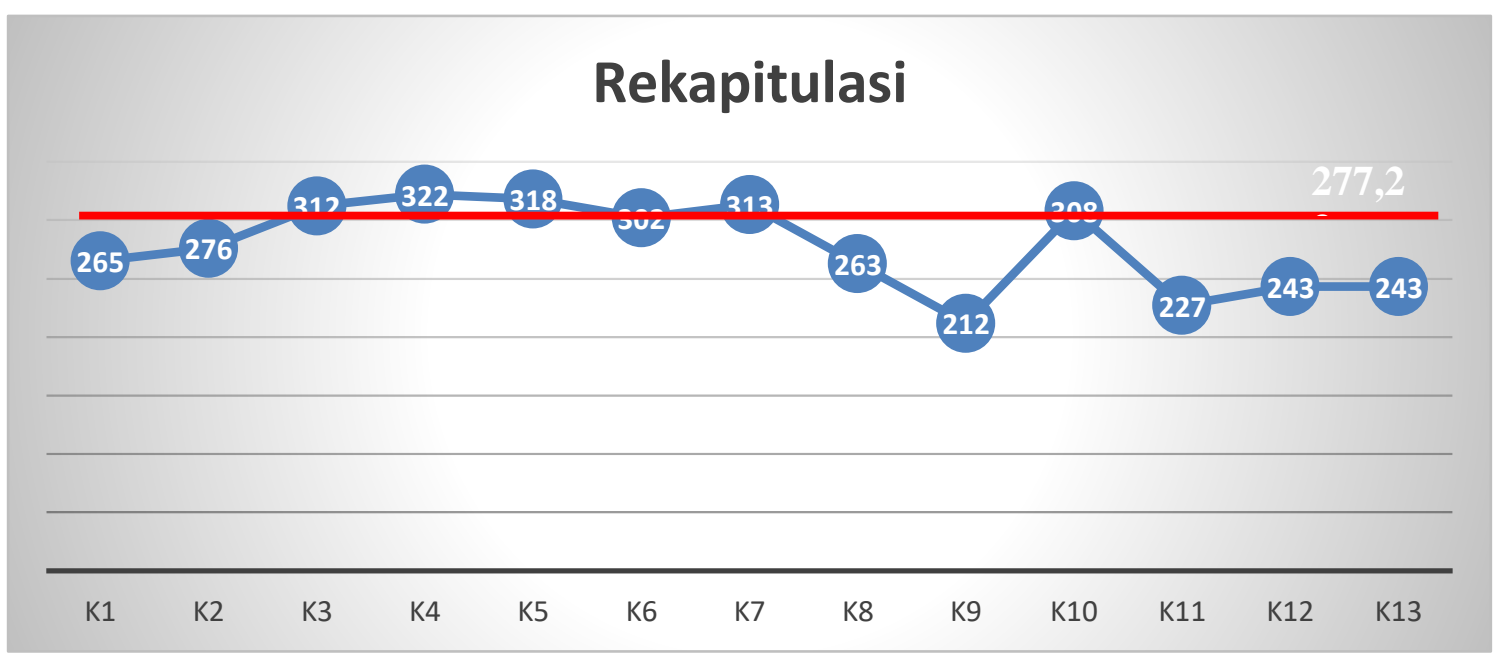

Gambar 8. Grafik Hasil Rekapitulasi

Berdasarkan data yang dilihat pada tabel diatas yang merupakan Kesimpulan Hasil penelitian dengan judul Metode Pengawasan Pencemaran Lingkungan Kota Palopo yang berfokus di kelurahan Pontap menggunakan parameter rekapitulasi kuesioner responden, dengan skala likert gradasi $0-80=$ Tidak Puas, $81-160=$ Kurang Puas, $161-240=$ Cukup Puas, $241-320=$ Puas dan $321-400=$ Sangat Puas. Penulis menyimpulkan bahwa Metode Pengawasan Pencemaran Lingkungan 
Kota Palopo dengan menggunakan parameter rekapitulasi kuesioner responden, 277,23 masuk pada gradasi puas, jadi masyarakat puas terhadap Metode Pengawasan Pencemaran Lingkungan di Kota Palopo yang mengambil sampel di Kelurahan Pontap Kecamatan Wara Timur Kota Palopo.

\section{KESIMPULAN}

Dari hasil penelitian "Metode Pengawasan Pencemaran Lingkungan Kota palopo", dengan menitik beratkan pada Pencemaran Air dan pengelolaan drainase di Kelurahan Pontap Kecamatan Wara Timur Kota Palopo. Tabel frekuensi dari hasil penelitian, menunjukkan rata-rata 277,23 dan dengan menggunakan Skala Likert masuk pada gradasi puas. Penelitian ini dapat disimpulkan bahwa Metode Pengawasan Pencemaran Lingkungan Kota palopo yang difokuskan di Kelurahan Pontap berjalan dengan baik atau dengan kata lain masyarakat puas terhadap metode pengawasan yang diberikan oleh pihak Pemerintah Kota Palopo dalam hal ini Pemerintah Kelurahan Pontap Kecamatan Wara Timur Kota Palopo.

Adapun hambatan yang timbul dalam pelaksanaan pengawasan lingkungan di Kelurahan Pontap yaitu, penggunaan drainase yang kurang maksimal karena masih ada warga dan para pengusaha kurang menyadari akan pentingnya drainase dalam kebersihan suatu lingkungan serta keterkaitannya dengan peningkatan perekonomian masyarakat. Dinas Kebersihan dan Pertamanan Kota Palopo sebaiknya menambah Unit Kontainer sampah (Koordinat: S 259’08” E 120¹1'55”) yang akan ditempatkan di Kelurahan Pontap Kecamatan Wara Timur.

\section{DAFTAR PUSTAKA}

Budiyati, Sri. (2012). Kesehatan Lingkungan. Bogor: Departemen Biologi FMIPA IPB Nugroho Tri Utomo DKK. (2015). Meningkatkan Gaya Hidup dan Kesehatan, Jakarta: Bappenas

Notoadmojo, Soekidjo. (2003). Prinsip-Prinsip Dasar Ilmu Kesehatan Masyarakat. Jakarta: Rineka Cipta Alfian

Sugiyono. (2009) : Metode penelitian Administrasi .Alpabeta.Bandung

R.Terry, George dan Leslie W.Rue. (2010). Dasar-Dasar Manajemen. Jakarta: Bumi. Aksara.

UNDANG - UNDANG / PERATURAN MENTERI

Undang-undang nomor 32 tahun 2009, tentang Perlindungan dan Pengelolaan Lingkungan Hidup (PPLH).

Pereaturan Menteri Linkungan Hidup No. 7 Tahun 2014, tentang Kerugian Lingkungan Hidup 